\title{
Exploring the lives of youth in the BPO sector: Findings from a study in Gurgaon
}

Monisha Vaid

Follow this and additional works at: https://knowledgecommons.popcouncil.org/departments_sbsr-rh

Part of the Demography, Population, and Ecology Commons, Family, Life Course, and Society Commons, International Public Health Commons, and the Public Health Education and Promotion Commons How does access to this work benefit you? Let us know!

\section{Recommended Citation}

Vaid, Monisha. 2009. "Exploring the lives of youth in the BPO sector: Findings from a study in Gurgaon," Health and Population Innovation Fellowship Programme Working Paper no. 10. New Delhi: Population Council. 
Exploring the Lives of Youth in the BPO Sector

\section{FINDINGS FROM A STUDY IN GURGAON}

Monisha Vaid

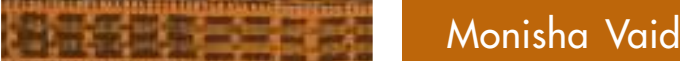

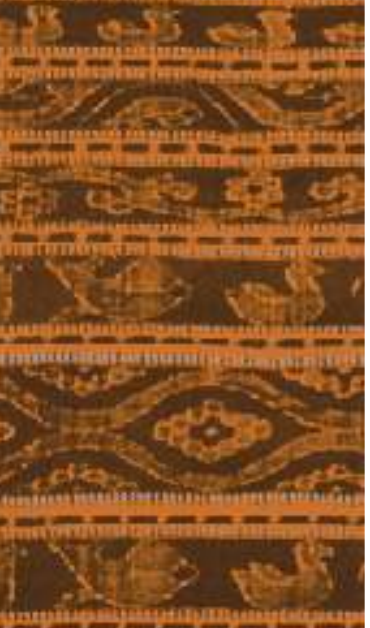
imit

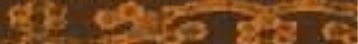

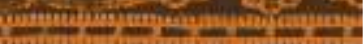

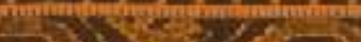

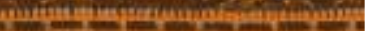

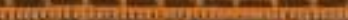

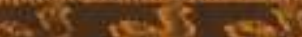

Health and Population Innovation Fellowship Programme Working Paper, No. 10 
This report is the result of a project entitled "Personal competencies, social network and risk taking: Understanding emerging issues among youth in BPOs" undertaken as part of the Health and Population Innovation Fellowship (HPIF) awarded to the author in 2005.

The HPIF programme is administered by the Population Council, New Delhi and is a continuation of the MacArthur Foundation's Fund for Leadership Development (FLD) fellowship programme that continued over the period 1995 to 2004. The Council is grateful to the MacArthur Foundation for its support to this programme.

The HPIF programme aims to support mid-career individuals who have innovative ideas, leadership potential, and the capacity to help shape policy and public debate in the field of population, reproductive health and rights in general, with a focus on two priority themes - maternal mortality and morbidity, and the sexual and reproductive health and rights of young people. Since the transfer of the programme to the Population Council through 2006, a total of 17 individuals have been supported under the HPIF programme.

\section{For additional copies of this report, please contact:}

Monisha Vaid

31 Arjun Marg

DLF Phase 1, Gurgaon

Haryana 122002

India

Email : mn_v_2000@yahoo.com
Population Council

Zone 5A, Ground Floor

India Habitat Centre

Lodi Road, New Delhi 110003

Phone: 011-24642901/02

Email: info-india@popcouncil.org

Web site: http://www.popcouncil.org/asia/india.html

The Population Council is an international, non-profit, non-governmental organisation that seeks to improve the well-being and reproductive health of current and future generations around the world and to help achieve a humane, equitable and sustainable balance between people and resources. The Council conducts biomedical, social science and public health research, and helps build research capacities in developing countries.

Copyright $(2009$ Monisha Vaid

About the author: Monisha Vaid has a Masters degree in Community Resource Management and Extension from Lady Irwin College, Delhi University (India). She has been involved in project development, implementation and monitoring of sexual and reproductive health programs and adolescent life skill building programs. Currently she is associated with Urban Health Resource Centre (UHRC) working on urban poor health issues.

Suggested citation: M. Vaid. 2009. "Exploring the Lives of Youth in the BPO Sector: Findings from a Study in Gurgaon", Health and Population Innovation Fellowship Programme Working Paper, No 10. New Delhi: Population Council.

\section{QP Population Council}




\section{Exploring the Lives of Youth in the BPO Sector}

\section{FINDINGS FROM A STUDY IN GURGAON}

\section{Monisha Vaid}

Fellow

Health and Population Innovation Fellowship Programme 


\section{Contents}

Introduction 1

Background 2

Study setting, methodology and limitations 4

Study setting 4

Methodology 4

Limitations 6

Profile of respondents 7

Socio-demographic characteristics 7

Work history 8

Residence patterns 10

Family connections and social networks 11

Family interaction 11

Family background, parental supervision and parental attitudes 11

Interaction with parents post-employment in the current BPO 14

Peer influences 15

Peer networks and social interaction 15

Peer behaviours 16

Support networks 17

Residence patterns and peer interaction patterns 18

Individual competencies 20

Awareness of sexual and reproductive health matters 22

Romantic partnerships, physical intimacy and sexual experiences 23

Romantic relationships

Physical intimacy and sexual experiences 24

Residence patterns and romantic and sexual experiences 28

Substance use 30

Summing up and recommendations 32

Summing up 32

Recommendations 33

References 35

Acknowledgements 37 


\section{List of tables and figures}

Table 1: Study sample

Table 2: $\quad$ Profile of respondents _ 7

Table 3: Work history _ 8

Table 4: $\quad$ Reasons for joining a BPO company and views about their current BPO job

Table 5: $\quad$ Residence patterns pre-employment and post-employment in current BPO

Table 6: Family background and parental supervision 12

Table 7: Perceptions of parental reactions towards respondents' relationships with same-sex and opposite-sex friends

Table 8: Interaction with parents post-employment in the current BPO company 15

Table 9: $\quad$ Peer networks and peer interaction 16

Table 10: Peer behaviours and experiences, as reported by respondents 17

Table 11: Leading confidante on personal, relationship and work-related problems 18

Table 12: Individual competencies post-employment in a BPO 21

Table 13: Awareness of reproductive and sexual health matters 22

Table 14: Romantic relations with an opposite-sex partner 23

Table 15: Experience of physical intimacy with an opposite-sex partner 24

Table 16: First sexual experience with an opposite-sex partner, among respondents reporting pre-marital sex

Table 17: Most recent sexual experience with opposite-sex partner, among respondents 26

Table 18: Extent of risky sex 27

Table 19: Substance use 30

Figure 1: Peer interaction by residence: \% BPO employees reporting that compared to their situation prior to joining the BPO they now had more friends, spent more time with friends and attended more late night parties

Figure 2: Peer connections: \% reporting friends as their leading confidante on various matters by residence

Figure 3: Romantic partnership and residence patterns 28

Figure 4: Physical intimacy by residence patterns 29

Figure 5: Substance use and residence patterns: \% reporting ever having smoked or consumed alcohol 


\section{Introduction}

The Indian economy has been growing rapidly since the 1990s as a result of the processes of globalisation, economic reform and liberalisation. Over the past decade, the services sector in particular has witnessed a high rate of growth, most notably in the information technology enabled services (ITES) and business process outsourcing (BPO) segments. ${ }^{1}$

India has been a leading destination for the location of offshore services. With a large population of young people, India has been well placed to meet the human resource requirements of a growing outsourcing services industry. ${ }^{2}$ India has a vast educated English-speaking workforce with computer skills; indeed, it is estimated that over 167,000 engineering students and approximately 1.5 million graduates are added each year to this young workforce (Phukan, 2003). Low operating and labour costs and a favourable policy environment are other factors that have contributed to the popularity of India as an outsourcing destination. As a result, numerous new employment opportunities have been created for educated young people, including fresh college graduates and post-graduates. It is estimated that in 2007-08, the information technology-BPO industry will provide direct employment to 2 million people in the country (Government of India, Department of Information and Technology, nd).

The tremendous growth of the BPO sector over the past few years has resulted in considerable changes in the lives of its young workforce. While few studies have explored these issues, limited information available from surveys and anecdotal evidence suggests that the BPO sector has had both positive and negative effects on the lives of young adults. Notably, unlike many other industries, the BPO sector provides opportunities for employment at a young age, high disposable incomes and quick promotional avenues. As a result, young professionals in the sector are reaching their career goals and financial targets much earlier than before. At the same time, evidence suggests that young BPO employees are adopting risky sexual behaviours, and excessive drug and alcohol use has also been reported among this sub-population.

This report seeks to fill gaps in information on the lives of unmarried youth in the BPO sector. Specifically, it documents young people's self-efficacy and their connections with their family and peers, as well as their sexual experiences and substance use practices.

\footnotetext{
${ }^{1}$ BPO companies are external providers that administer and manage one or more information technology intensive business processes based on defined and measurable performance criteria.

2 Youth aged 10-24 years in India constitute 31 percent (315 million) of the country's population of 1.1 billion (RGI, 2001) and 42.4 per cent of those aged 15-24 are working (calculated from the 2001 census).
} 


\section{Background}

The information technology and ITES-BPO industry in India has grown rapidly, registering a compound annual growth rate (CAGR) of 26 percent over the last decade. The number of information technology and ITES-BPO professionals employed in India increased from 284,000 in 1999-2000 to over 1.6 million in 2006-07 (Government of India, Department of Information and Technology, nd). With 70 percent of the workforce in the age group 26-35 years, the IT-ITES industry is likely to become one of the largest employers of young adults in India. Currently Bangalore, Mumbai, the National Capital Region (NCR), Hyderabad, Pune, Chennai and Kolkata account for 90 per cent of the total direct employment in the BPO sector. BPO sector employment involves, for the most part, such activities as customer care services, data entry and analysis, payment processing services, audit checks for companies and so on. Typically, each BPO employee responds to a minimum of 100 phone calls per shift. (Sharma, n.d.).

Aside from attractive salaries, the attractive work environment and benefits offered by the BPO sector have motivated many young adults to seek employment in this sector (Sharma, 2004). For example, the majority of BPOs provide provident fund, gratuity, group mediclaim insurance schemes (for employees as well as their spouse, non-earning parents and children), personal accident insurance scheme, subsidized food and transportation. Also provided by many BPOs are performance based incentives, flexi-time, flexible salary benefits, paid days off, maternity leave, and an employee stock option plan. Recreational facilities are also available in BPOs; these include pool tables, chess tables and coffee bars, and some even have well equipped gyms, personal trainers and many organise regular get together and other cultural programs for staff. Some even provide company leased (shared) accommodation for out-station employees, corporate credit card facilities, cellular phones/laptops, medical check-ups, loans and educational benefits. (Sharma, 2004).

The BPO sector has opened up vast career opportunities for young adults, but at the same time employment in the sector has had an impact on young people's lives. For example, several young BPO employees have had to relocate to outsourcing hubs and live independently. With the availability of higher disposable incomes, many young people have reported lifestyle changes. Indeed, among financially independent youth there has been a visible move towards consumerism (Phukan, 2006).

While employment in the BPO sector has meant that young adults are reaching their career milestones and financial goals much earlier than before, surveys and anecdotal evidence show that workers in the BPO sector experience high levels of stress as a result of working in closely monitored environments with pressure to meet ambitious performance targets. Strict deadlines and ambitious targets have also resulted in employee "burnout". Repetitive tasks, such as responding to telephone calls more than 100 times a shift have resulted in absenteeism and attrition among many young employees (Sharma, n.d.). A growing number of employees also experience physical and emotional problems such as panic attacks, depression, relationship problems, alcoholism and sleeping and 
eating disorders (Phukan, 2006; e-sat survey, 2005). According to a survey of BPO employees, several factors were considered to cause stress at work including travel time, changing duty shifts, insufficient holidays, work pressure and long working hours (http://www.livemint.com/2007/11/17012831/Long-working-hours-travel-tim.html).

Moreover, as many BPOs provide services to countries overseas, employees in the sector are trained to understand the culture and accent of these countries; in some cases, employees are required to use a different name, speak in a foreign accent and adopt a different persona at work, which may result in anxiety and related disorders (Pradhan and Abraham, 2005).

There is a growing concern in various sectors, including the government, about the health and safety of young BPO employees. The Health Ministry is considering issuing guidelines for employees in this sector. However, the lack of reliable information on which to base a response to such concerns poses a challenge to safeguarding the health of these young professionals. 


\section{Study setting, methodology and limitations}

\section{Study setting}

The study, conducted in 2006, was located in Gurgaon, one of India's major outsourcing hubs. Approximately 42 Indian and international BPOs operate in Gurgaon, of which some 20 BPOs service international clients (Call Centre Association of India, verbal communication).

Gurgaon city, with a population of about 228,820 (RGI, 2001), is located in the northern state of Haryana. Situated $30 \mathrm{~km}$ from the heart of New Delhi, Gurgaon is one of New Delhi's four major satellite cities, and is considered to be a part of the National Capital Region (NCR).

\section{Methodology}

The study was conducted in two international BPO companies, which were opportunistically selected. Initially, all 20 BPO companies in Gurgaon that cater to international clients were contacted. Of the 10 companies that responded, only two consented to allow the research to be conducted among their staff. Both companies are headquartered in the United States, provide customer care and billing services to their client companies; employees work in three shifts round the clock. The remaining eight companies refused to participate in the study for various reasons, including because the nature of questions being asked was perceived to be 'sensitive', the company did not want to burden their workforce, or the management did not allow research to be conducted.

The study consisted of both a qualitative and a quantitative phase. In the first phase, 10 key informant interviews (KIIs) were conducted in the two selected BPO companies with team leaders, communication trainers, human resources managers and senior customer service representatives to explore their perceptions of the changes that employment in the $\mathrm{BPO}$ sector brings in the lives of young adults.

In the second phase, a cross-sectional survey was conducted amongst male and female employees in the two BPO companies. The survey was conducted using a selfadministered questionnaire, developed on the basis of inputs obtained from other youth questionnaires as well as insights from the qualitative phase of the study (Cleland, 2001; IIPS and Population Council, 2005). The survey covered a range of topics including respondents' family background, nature of interaction with parents, parental attitudes to romantic partnerships, interaction with peers, self-efficacy after joining the BPO, knowledge of sexual and reproductive health issues, attitudes towards sexuality, substance use and sexual experiences. As all BPO employees are fluent in English, the questionnaires were prepared in English. 
Respondents were not contacted directly by the research team. In each BPO company, team leaders were asked to distribute the self-administered questionnaires to employees who met the selection criteria - that is, young men and women who were unmarried, aged 20-25 years and had worked in a BPO company for at least six months. Along with the questionnaire, respondents were provided a self-adhesive envelope, an instruction sheet and an informed consent statement.

To ensure a representative sample, team leaders were instructed to distribute the questionnaires equally amongst males and females, and amongst employees in each of the three work shifts. Team leaders were also required to distribute the forms for informed consent and instructions on how to fill the questionnaire to respondents.

Respondents were asked to seal and hand over the completed questionnaires to their team leaders; these envelopes were then collected by the research team. Respondents were informed that participation in the survey was voluntary.

In all, 800 and 1,800 questionnaires were given to team leaders in BPO A and BPO B, respectively, to distribute among eligible respondents. A total of 1,842 completed questionnaires were received from the two BPO companies, which included 960 by females and 882 by males (see Table 1), with an overall response rate of 71 percent. A moderate response rate has also been observed in other studies that used similar selfadministered survey questionnaires (Elul et al., 2006). In order to preserve the confidentiality of eligible respondents, completed questionnaires were returned into a sealed box and no effort was made to identify those who did not respond.

Data are presented by way of bivariate analyses; tests for significance between responses of young men and women are presented, as appropriate.

\section{Table 1:}

Study sample

\begin{tabular}{|l|r|r|r|}
\hline & BPOA & BPO B & Total \\
\hline $\begin{array}{l}\text { Number of questionnaires distributed to } \\
\text { team leaders }\end{array}$ & & & \\
\hline $\begin{array}{l}\text { Young men } \\
\text { Young women }\end{array}$ & 400 & 900 & 1,300 \\
Total & 800 & 900 & 1,300 \\
Number of completed questionnaires & & 1,800 & 2,600 \\
\hline Young men & 240 & & \\
Young women & 260 & 700 & 882 \\
Total & 500 & 1,342 & 1,842 \\
Response rate (\%) & & & \\
Young men & 60.0 & 71.3 & 67.8 \\
Young women & 65.0 & 77.8 & 73.8 \\
Total & 62.5 & 74.6 & 70.8 \\
\hline
\end{tabular}




\section{Limitations}

The limitations of the study design must be acknowledged and findings must be interpreted with caution. First, the study design did not include a control group; in the absence of a control group, it was not possible to assess the extent to which youth in BPOs differed from educated urban youth more generally, and therefore to establish that it was indeed employment in the BPO sector that influenced changes in their lives. Second, as researchers were not in direct contact with the respondents, they could not ensure that the guidelines for completing the questionnaire were followed; additionally, they could not provide feedback on problems respondents may have encountered while completing the questionnaire. Third, because researchers were not provided direct access to respondents, it was not possible to conduct in-depth interviews that probed employee behaviours and BPO experiences more fully. Finally, we caution readers that the sample may not be representative of all BPO employees because both the BPOs and the study participants were opportunistically selected and because one-third of the sample did not complete the questionnaire. 


\section{Profile of respondents}

This section presents a socio-demographic profile of respondents, their work history and patterns of residence.

\section{Socio-demographic characteristics}

As can be seen in Table 2, the mean age of respondents was 24 years. Young women tended to be relatively older than young men; 61 percent of young women compared to 54 percent of young men were in the age group 24-25 years. All respondents had an undergraduate degree, which is a prerequisite for employment in a BPO. However, while more than 65 percent of both young men and women reported that they had only a general undergraduate degree, one-third of youth had in addition, a post-graduate degree/diploma.

Respondents were asked to report on their family's economic status (affluent, middle class, lower middle class). Survey findings indicate that while the majority of the young educated workforce (over $80 \%$ ) reported that they were from lower middle class families, $15-18 \%$ reported they were from middle class families. The large majority of young men and women (over 90\%) reported that both parents were alive.

\section{Table 2:}

Profile of respondents

\begin{tabular}{|c|c|c|}
\hline Characteristic & $\begin{array}{l}\text { Young men } \\
(\mathrm{N}=\mathbf{8 8 2})\end{array}$ & $\begin{array}{l}\text { Young women } \\
(\mathrm{N}=960)\end{array}$ \\
\hline \multicolumn{3}{|l|}{ Age** $_{(\%)}$} \\
\hline 20-21 yrs & 9.5 & 5.2 \\
\hline $22-23$ yrs & 36.1 & 33.6 \\
\hline $24-25$ yrs & 54.4 & 61.1 \\
\hline Mean age & 23.6 & 23.7 \\
\hline \multicolumn{3}{|l|}{ Education (\%) } \\
\hline Undergraduate degree & 67.0 & 64.9 \\
\hline Professional diploma & 14.1 & 18.5 \\
\hline Post-graduate degree & 18.9 & 16.6 \\
\hline \multicolumn{3}{|c|}{ Family's economic status** (\%) } \\
\hline Middle class & 18.3 & 14.5 \\
\hline Lower middle class & 81.7 & 85.5 \\
\hline \multicolumn{3}{|c|}{ Parents' survival status (\%) } \\
\hline Both parents alive & 90.9 & 90.5 \\
\hline \multicolumn{3}{|l|}{${ }^{*} p<=.01 ; * * p<=.001$} \\
\hline
\end{tabular}




\section{Work history}

The study explored respondents' employment history as well as their experiences of working in the BPO sector, including the reasons why they had joined the BPO sector, and what they liked and disliked most about their current BPO job.

Findings, presented in Table 3, show that most young BPO employees had started working at age 21. However, 16 percent of young men, as compared to 12 percent of young women, had started working early, that is, before age 20. Fewer than 40 percent of respondents reported that their current job was their first job.

Gender differences were evident with regard to young people's employment history in the BPO sector. Young men were far more likely than young women (59\% versus 38\%) to have worked in more than one BPO company. Moreover, though similar percentages of young men and women had worked in the BPO sector for about one year, a considerably larger proportion of young women than young men (20\% versus $7 \%$ ) had worked in the sector for more than three years. Findings suggesting that young men were more likely than young women to have worked for multiple BPO companies but had worked for shorter periods suggest that young men were more mobile than young women in the $\mathrm{BPO}$ sector.

Table 3:

Work history

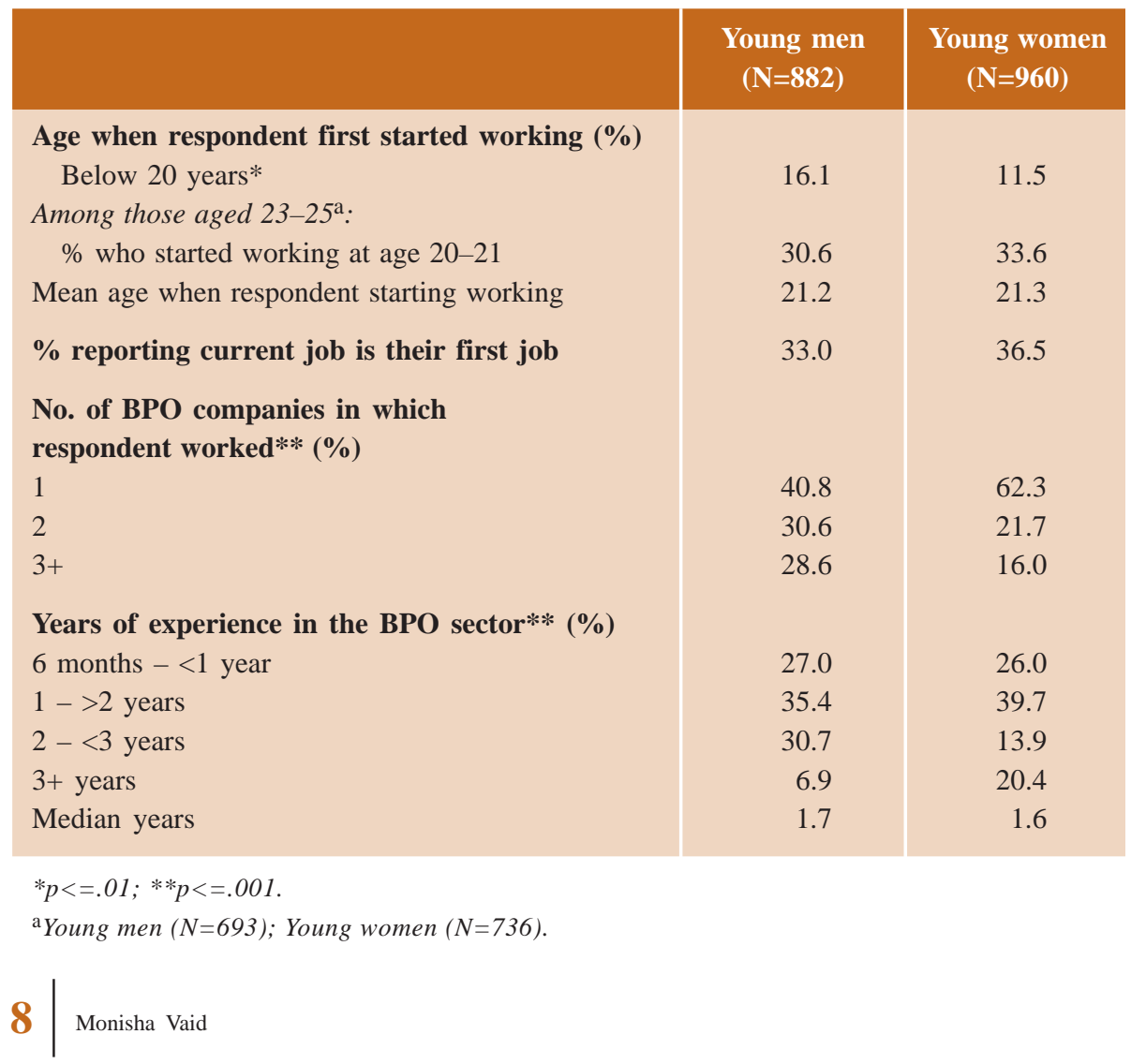


Though gender differences were wide, the leading reason for joining a BPO company cited by most young adults ( $72 \%$ of young men and $77 \%$ of young women) was the high starting salary paid in this sector (Table 4). Other reasons were reported fewer young adults; for example, just one-quarter of young men and two-fifths of young women reported job prospects as the leading reason.

Not surprisingly, the most appealing aspect of their current BPO job, identified by both young men and young women, was also the high salary they were being paid. Other appealing aspects of their current job were the working environment (reported by $41 \%$ of young men and $57 \%$ of young women) the nature of work in the BPO company

Table 4:

Reasons for joining a BPO company and views about their current BPO job

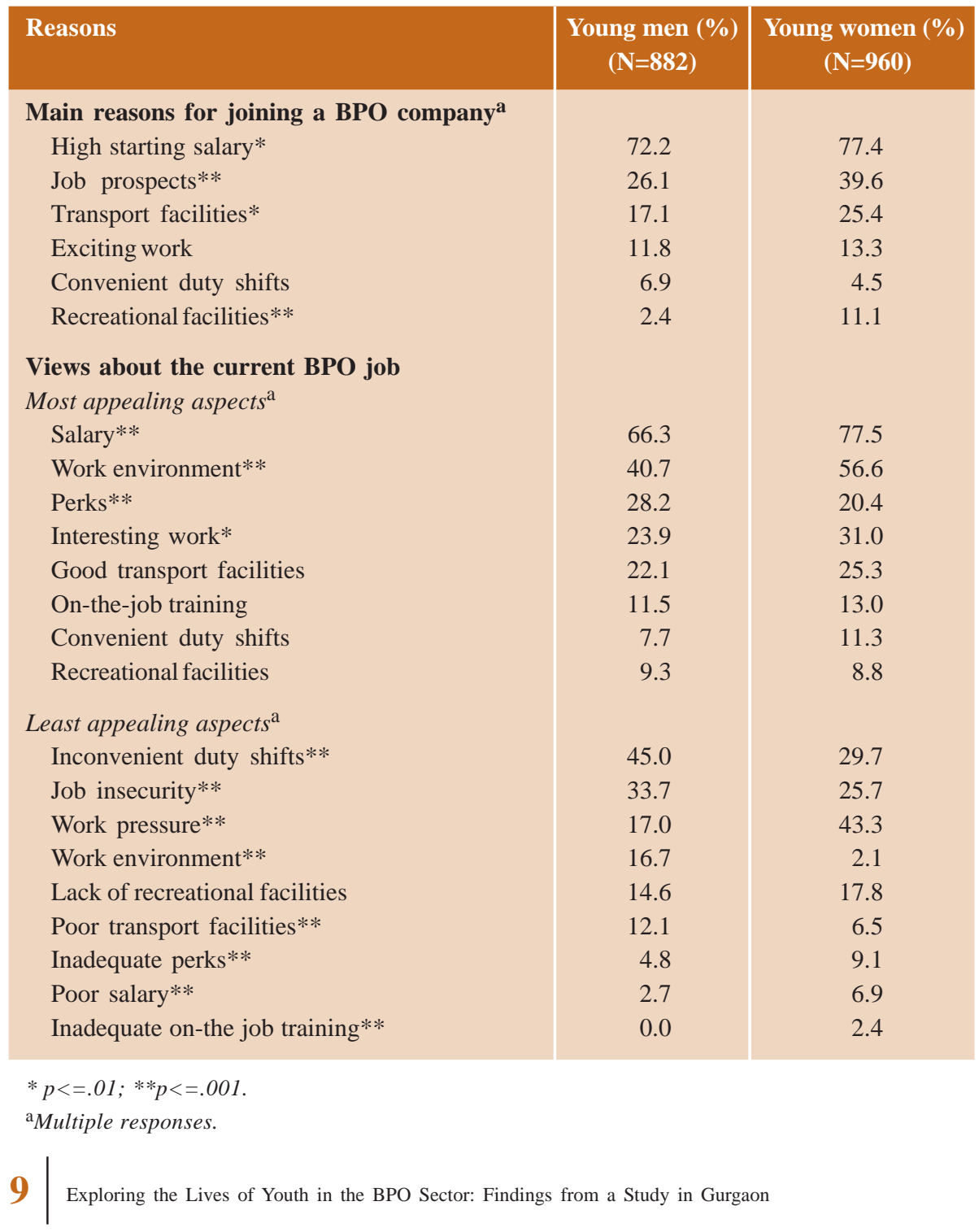


(reported by $24 \%$ and $31 \%$ of young men and women, respectively) and perks of the job (reported by $28 \%$ and 20\%, respectively). Both young men and women also listed transport facilities (22-25\%).

Young men and women reported different aspects of their current job they most disliked. Young men were more likely to report inconvenient duty shifts and job insecurity while young women tended to cite pressure to meet ambitious targets as well as inconvenient duty hours as the main drawbacks of their current job.

\section{Residence patterns}

Young professionals' patterns of residence before and after joining the current BPO are presented in Table 5. The majority of BPO employees (over 70\%) were currently residing on their own or with friends/colleagues in a rented accommodation. A notable finding is that a considerably larger proportion of young women than young men had left their parental homes to live independently after joining the current BPO. While only 14 percent of young women were living away from their parental homes before working in the current company, after employment, the proportion of young women living independently increased to 62 percent. In contrast, one-third of young men (38\%) were already staying on their own or with friends and colleagues before joining the current company; following employment in the company, the proportion of young men staying independently increased to 62 percent. Clearly, the gender differences in residence patterns apparent prior to employment in the BPO had completely disappeared following BPO employment.

Table 5:

Residence patterns pre-employment and post-employment in current BPO

\begin{tabular}{l|c|c|c|c|}
\multirow{2}{*}{ Residence } & \multicolumn{3}{|c|}{ Young men (N=882) } & \multicolumn{2}{c|}{ Young women (N=960) } \\
\cline { 2 - 6 } & $\begin{array}{c}\text { Pre- } \\
\text { employment } \\
\text { in current } \\
\text { BPO*\% \% }\end{array}$ & $\begin{array}{c}\text { Post- } \\
\text { employment } \\
\text { in current } \\
\text { BPO \% }\end{array}$ & $\begin{array}{c}\text { Pre- } \\
\text { employment } \\
\text { in current } \\
\text { BPO \% }\end{array}$ & $\begin{array}{c}\text { Post- } \\
\text { employment } \\
\text { in current } \\
\text { BPO \% }\end{array}$ \\
\hline $\begin{array}{l}\text { Living with one or both } \\
\text { parents }\end{array}$ & 48.1 & 28.3 & 79.5 & 29.8 \\
\hline $\begin{array}{l}\text { Living with relatives } \\
\text { Living with friends/colleagues }\end{array}$ & 13.5 & 9.7 & 6.3 & 8.6 \\
\hline Living alone & 28.9 & 38.1 & 2.3 & 38.6 \\
\end{tabular}

${ }^{*} p<=.01 ; * * p<=.001$. 


\section{Family connections and social networks}

Studies have highlighted the importance of close parental interaction for the healthy development of youth (Laird et al., 2003; Marta, 1997; Sroufe, 1991); others have noted that young people's interaction with parents is particularly limited when it comes to discussing sensitive issues such as boy-girl relationships (Alexander et al., 2006a; 2006b; Lambert and Wood, 2005; Mehra and Coutinho, 2002). Evidence also shows that the peer group is, for many young people, a central source of both information and support, but at the same time a source of misinformation and pressure to adopt risky behaviours; for example, one study of youth in Pune district reports that peers were reported to be the leading confidante for youth on matters related to relationships and sex and reproduction; at the same time, overall levels of awareness about sexual and reproductive matters was limited among them (Alexander et al., 2006a).

This section explores BPO employees' family characteristics, socialisation experiences, and parental attitudes to youth friendships and social activities. It also describes BPO employees' peer networks, interaction with same-sex and opposite sex friends and peer risk behaviours, and explores young people's access to support networks to discuss personal matters. Young people's interaction with peers and parents after joining the BPO sector is also discussed. Finally, we explore whether youth behaviours and experience differ according to whether they reside together with parents or independently.

\section{Family interaction}

\section{Family background, parental supervision and parental attitudes}

Respondents were asked whether they believed their parents held traditional attitudes, whether their family life had been characterised by conflict and the extent of communication within the family. Most young adults reported that their family held non-traditional values (Table 6). Although BPO employees reported close and open communication with their parents, both young men and young women also reported some family conflict.

The study explored BPO employees' socialisation experiences when they were growing up and their current experiences. Not surprisingly, young adults reported stricter supervision when they were growing up as compared to more recently for most themes explored. For example, 85-95\% of young men and women reported that their parents had been strict about them returning home on time at night when they were growing up, fewer $(66-70 \%)$ reported that their parents were still strict about them being back home on time. Gender differences were wide with regard to experiences of parental supervision while growing up, with young women significantly more likely than young men to report that their parents had been strict about their choice of clothes (69\% versus 56\%) and being back home at night on time (95\% versus $85 \%$ ). In contrast, gender differences in parental supervision at the time of interview were narrow. 


\section{Table 6:}

Family background and parental supervision

\begin{tabular}{|c|c|c|}
\hline Characteristics (\%) & $\begin{array}{l}\text { Young men } \\
(\mathrm{N}=\mathbf{8 8 2})\end{array}$ & $\begin{array}{l}\text { Young women } \\
(\mathrm{N}=960)\end{array}$ \\
\hline \multicolumn{3}{|l|}{ Family environment } \\
\hline Non-traditional family values ${ }^{\#}$ & 79.5 & 74.8 \\
\hline Very open family communication ${ }^{\# *}$ & 57.9 & 63.9 \\
\hline No family conflict ${ }^{\#}$ & 37.8 & 24.4 \\
\hline \multicolumn{3}{|l|}{ Parental supervision } \\
\hline \multicolumn{3}{|l|}{$\begin{array}{l}\text { Parents strict about respondents being back home } \\
\text { at night on time }\end{array}$} \\
\hline At around age $16^{* *}$ & 85.3 & 95.3 \\
\hline Currently & 65.8 & 69.9 \\
\hline \multicolumn{3}{|l|}{ Parents strict about respondents' choice of friends } \\
\hline At around age 16 & 70.9 & 74.7 \\
\hline Currently & 55.9 & 54.5 \\
\hline \multicolumn{3}{|l|}{ Parents vigilant about respondents spending money } \\
\hline At around age $16^{* *}$ & 85.7 & 71.0 \\
\hline Currently & 63.3 & 57.7 \\
\hline \multicolumn{3}{|l|}{ Parents strict about respondents' choice of clothes } \\
\hline At around age $16^{* *}$ & 56.1 & 68.5 \\
\hline Currently** & 41.7 & 54.7 \\
\hline \multicolumn{3}{|l|}{ Interaction with parents } \\
\hline \multicolumn{3}{|l|}{ Parents spent/spend a lot of time with respondent } \\
\hline At around age $16^{* *}$ & 43.9 & 61.1 \\
\hline Currently** & 11.9 & 26.8 \\
\hline \multicolumn{3}{|l|}{ Parents very understanding } \\
\hline At around age $16^{* *}$ & 38.5 & 55.4 \\
\hline Currently** & 48.1 & 66.3 \\
\hline \multicolumn{3}{|l|}{ Financial support to parents } \\
\hline Regularly sends part of salary to parents** & 16.8 & 40.8 \\
\hline
\end{tabular}

${ }^{*} p<=.01 ; *^{* *} p<=.001$.

${ }^{\#}$ Questions were: "Where would you place your family on the following: how traditional is your family? How openly do your family members communicate with each other? How much conflict or fighting is there among your family members?" 
Although BPO employees noted that they spent less time with their parents at the time of interview as compared to when they were growing up, many young adults continued to share a close and understanding relationship with their parents. Young women were far more likely than young men to report close family interaction. For example, 27 percent of young women as compared to 12 percent of young men noted that their parents were currently spending a lot of time with them, and 66 percent and 48 percent respectively, noted that their parents were very understanding. A notable finding is that two-fifths of young women (41\%), as compared to 17 percent of young men, supported their families with their earnings.

Evidence on parent-child relationships in India suggests that parents disapprove of social activities in which youth tend to participate, particularly those involving members of the opposite sex (IIPS and Population Council, 2009). Findings from our study, however, indicate that parents were fairly tolerant of youth friendships and social activities (Table 7). More than $90 \%$ of young men and more than $80 \%$ of young women, for example, perceived that their parents would not disapprove of their friendships with opposite-sex colleagues or if they attended parties with both male and female friends. Similarly, most respondents noted that their mother and father would not be angry if they had a love marriage or if they went to see a film with an opposite-sex friend.

Young women were, however, significantly more likely than young men to report the perception of parental disapproval in reference to most themes. For example, 17 percent of young women as compared to 9 percent of young men reported expecting parental disapproval if they were friendly with an opposite-sex colleague, and 37 percent of young women as compared to 12 percent of young men reported their parents would disapprove of them having a boyfriend/girlfriend. A similar pattern was seen in the case of mothers' or fathers' reactions to young women and young men going out with opposite-sex friends to watch a film (25\% versus $16 \%$ perceived their mother would be angry; $35 \%$ versus $19 \%$ perceived their father would be angry). Likewise, more young women than young men expected parental disapproval if they had a love marriage ( $27 \%$ versus $17 \%$ reported their mother would be angry while $29 \%$ versus $22 \%$ reported their father would be angry). 


\section{Table 7:}

Perceptions of parental reactions towards respondents' relationships with same-sex and opposite-sex friends

\begin{tabular}{|c|c|c|}
\hline Perceptions of parental reactions (\%) & $\begin{array}{l}\text { Young men } \\
(\mathrm{N}=\mathbf{8 8 2})\end{array}$ & $\begin{array}{l}\text { Young women } \\
(\mathrm{N}=960)\end{array}$ \\
\hline \multicolumn{3}{|l|}{ Parents would disapprove if respondent: } \\
\hline Was friendly with opposite-sex colleagues** & 9.2 & 17.2 \\
\hline $\begin{array}{l}\text { Went to parties with both male and } \\
\text { female friends** }\end{array}$ & 9.3 & 20.1 \\
\hline Had a girl/boyfriend** & 11.6 & 37.0 \\
\hline \multicolumn{3}{|l|}{ Mother would be angry if respondent: } \\
\hline Went to see a film with an opposite-sex friend** & 16.2 & 24.9 \\
\hline Had a love marriage** & 16.8 & 27.2 \\
\hline \multicolumn{3}{|l|}{ Father would be angry if respondent: } \\
\hline Went to see a film with an opposite-sex friend** & 18.9 & 35.3 \\
\hline Had a love marriage** & 21.9 & 28.8 \\
\hline
\end{tabular}

\section{Interaction with parents post-employment in the current BPO}

Employment in the current BPO appears to have curtailed the time that young adults spend with their parents, with more than 80 percent of respondents acknowledging that they were spending less time with their parents after they had started working in the current company as compared to before (Table 8). However, those residing away from their parents reported being in regular contact with their mother and father, with more than one-third of both young men and young women reporting that they met their parents regularly even after employment in the BPO. A significantly larger proportion of young women than young men ( $84 \%$ versus $66 \%$ ) reported regularly speaking to their parents over the telephone. 


\section{Table 8:}

Interaction with parents post-employment in the current BPO company

\begin{tabular}{|c|c|c|}
\hline Interaction with parents & $\begin{array}{l}\text { Young men } \\
(\mathbf{N}=\mathbf{8 8 2})\end{array}$ & $\begin{array}{l}\text { Young women } \\
\qquad(\mathrm{N}=960)\end{array}$ \\
\hline $\begin{array}{l}\text { \% reporting they spent as much/more time with } \\
\text { parents post-employment than before joining the } \\
\text { current BPO }\end{array}$ & 15.9 & 17.4 \\
\hline $\begin{array}{l}\text { Of those living separatelya, \% who: } \\
\text { Talked with their parents on the telephone } \\
\text { everyday/a couple of days a week } \\
\text { post-employment** } \\
\text { Met their parents a few days a week/month } \\
\text { post-employment }\end{array}$ & $\begin{array}{l}66.4 \\
36.7\end{array}$ & $\begin{array}{l}83.8 \\
35.0\end{array}$ \\
\hline
\end{tabular}

\section{Peer influences}

\section{Peer networks and social interaction}

As most BPO employees were staying on their own or with friends, it is not surprising that the vast majority (over 90\%) reported having peers with whom they could discuss personal matters (Table 9). Working in a BPO appears to have influenced the extent of young BPO employees' peer networks and their interaction with peers. Though gender differences were wide, both young men and young women reported that as compared to the situation before they were employed in this sector, after joining a BPO they had more friends (46\% and 32\%, respectively) and had started attending late night parties more frequently (43\% and 39\%, respectively).

Most BPO employees acknowledged that they went out with their opposite-sex friends; however, young men were significantly more likely than young women (26\% versus 16\%) to go out often with their opposite-sex friends. The places young adults visited most frequently with opposite-sex friends were restaurants, shopping complexes and pubs. 


\section{Table 9:}

Peer networks and peer interaction

\begin{tabular}{|c|c|c|}
\hline Peer interaction (\%) & $\begin{array}{l}\text { Young men (\%) } \\
(\mathrm{N}=\mathbf{8 8 2})\end{array}$ & $\begin{array}{l}\text { Young women (\%) } \\
\qquad(\mathrm{N}=960)\end{array}$ \\
\hline $\begin{array}{l}\text { Peer networks } \\
\text { Had friends (male or female) with whom they } \\
\text { could discuss personal matters }\end{array}$ & 95.1 & 92.9 \\
\hline $\begin{array}{l}\text { Following employment in a BPO they: } \\
\text { Had more friends than before** } \\
\text { Spent more time with friends than before** } \\
\text { Attended more late night parties than before }\end{array}$ & $\begin{array}{l}45.6 \\
26.5 \\
43.1\end{array}$ & $\begin{array}{l}32.0 \\
16.5 \\
38.5\end{array}$ \\
\hline $\begin{array}{l}\text { Frequency of going out with opposite-sex } \\
\text { friends** }\end{array}$ & & \\
\hline Never & 2.3 & 11.9 \\
\hline Sometimes & 66.7 & 67.6 \\
\hline Often & 26.4 & 15.8 \\
\hline $\begin{array}{l}\text { Do not have opposite sex friends } \\
\text { Of those who had opposite sex friend }\end{array}$ & 4.6 & 4.7 \\
\hline $\begin{array}{l}\text { Places visited most frequently with } \\
\text { opposite-sex friends }{ }^{\text {b }}\end{array}$ & & \\
\hline Shopping complexes & 40.2 & 40.5 \\
\hline Pubs/discotheques** & 35.9 & 24.3 \\
\hline Restaurants** & 32.7 & 49.9 \\
\hline Movie theatre & 23.2 & 26.1 \\
\hline Friend's house & 10.1 & 9.8 \\
\hline
\end{tabular}

\section{Peer behaviours}

BPO employees were asked about peer behaviours, including substance use among peers and the sexual experiences of their peers (Table 10). Most young adults reported that they had friends who smoked and consumed alcohol, had experienced a romantic partnership and had engaged in premarital sex. 
Gender differences were evident for all peer behaviours probed. Almost all young men reported that they had at least one friend who smoked or consumed alcohol $(97 \%$ reporting each); in contrast, fewer young women reported friends who smoked or consumed alcohol (63\% and 72\%, respectively). Almost all young men and women (95-98\%) reported friends who had a romantic partner; however, significantly more young men than young women (76\% versus 64\%) noted that at least one friend had engaged in premarital sex.

\section{Table 10:}

Peer behaviours and experiences, as reported by respondents

\begin{tabular}{|l|c|c|}
\hline Peer behaviours and experiences & $\begin{array}{c}\text { Young men (\%) } \\
(\mathbf{N}=\mathbf{8 8 2})\end{array}$ & $\begin{array}{c}\text { Young women (\%) } \\
(\mathbf{N}=\mathbf{9 6 0})\end{array}$ \\
\hline Had at least one friend who: & & \\
\hline Smoked** & 97.4 & 63.0 \\
\hline Consumed alcohol** & 97.4 & 72.4 \\
\hline Had a romantic partner* & 95.0 & 97.9 \\
Had engaged in premarital sex** & 76.4 & 64.1 \\
\hline${ }^{*}<=.01 ; * * p<=.001$. & & \\
\hline
\end{tabular}

\section{Support networks}

Respondents were asked about the person with whom they were most likely to discuss personal matters, boy-girl relationships and work issues. Not surprisingly, given the finding that most BPO employees were not living with their parents, both young men and young women reported friends/colleagues as their leading confidante on all these issues (Table 11). Gender differences were evident, with significantly more young men than women reporting friends/colleagues as their leading confidante with whom they discussed these issues. Amongst family-level confidantes, it is interesting to note that while both young men and women were more comfortable sharing personal problems with their mother than with their father, more respondents reported sharing work-related problems with their father than with their mother. 


\section{Table 11:}

Leading confidante on personal, relationship and work-related problems

\begin{tabular}{|l|c|c|c|c|c|c|}
\hline \multirow{2}{*}{$\begin{array}{l}\text { Leading } \\
\text { confidante }\end{array}$} & \multicolumn{3}{|c|}{ Young men (N=882) } & \multicolumn{3}{c|}{ Young women (N=960) } \\
\cline { 2 - 8 } & $\begin{array}{c}\text { Personal** } \\
\text { problem } \\
\text { discussed }\end{array}$ & $\begin{array}{c}\text { Boyfriend/ } \\
\text { girlfriend** } \\
\text { problem } \\
\text { discussed }\end{array}$ & $\begin{array}{c}\text { Work** } \\
\text { problem } \\
\text { discussed }\end{array}$ & $\begin{array}{c}\text { Personal** } \\
\text { problem } \\
\text { discussed }\end{array}$ & $\begin{array}{c}\text { Boyfriend/ } \\
\text { girlfriend** } \\
\text { problem } \\
\text { discussed }\end{array}$ & $\begin{array}{c}\text { Work** } \\
\text { problem } \\
\text { discussed }\end{array}$ \\
\hline Mother & 23.9 & 16.9 & 11.9 & 31.6 & 29.9 & 9.7 \\
\hline Father & 13.7 & 11.2 & 16.4 & 11.1 & 4.4 & 24.4 \\
\hline Brother/sister & 11.8 & 16.4 & 9.7 & 13.8 & 20.3 & 11.5 \\
\hline Friend/colleague & 50.6 & 55.4 & 62.0 & 43.6 & 45.4 & 54.5 \\
\hline
\end{tabular}

${ }^{*} p<=.01 ; * * p<=.001$.

\section{Residence patterns and peer interaction patterns}

A commonly heard assertion about youth in BPOs is that independent residence patterns may be associated with increased peer interaction. Figures 1 and 2 lend some support to this assertion. Findings suggest that an increase in the number of friends following employment in the BPO sector was more likely to be reported by youth who co-resided with their parents than those who resided on their own (significant only in the case of young women). Conversely, an increase in late night partying was significantly more likely to be reported by those residing on their own than those co-residing with parents.

\section{Figure 1:}

Peer interaction by residence: \% BPO employees reporting that compared to their situation prior to joining the BPO they now had more friends, spent more time with friends and attended more late night parties

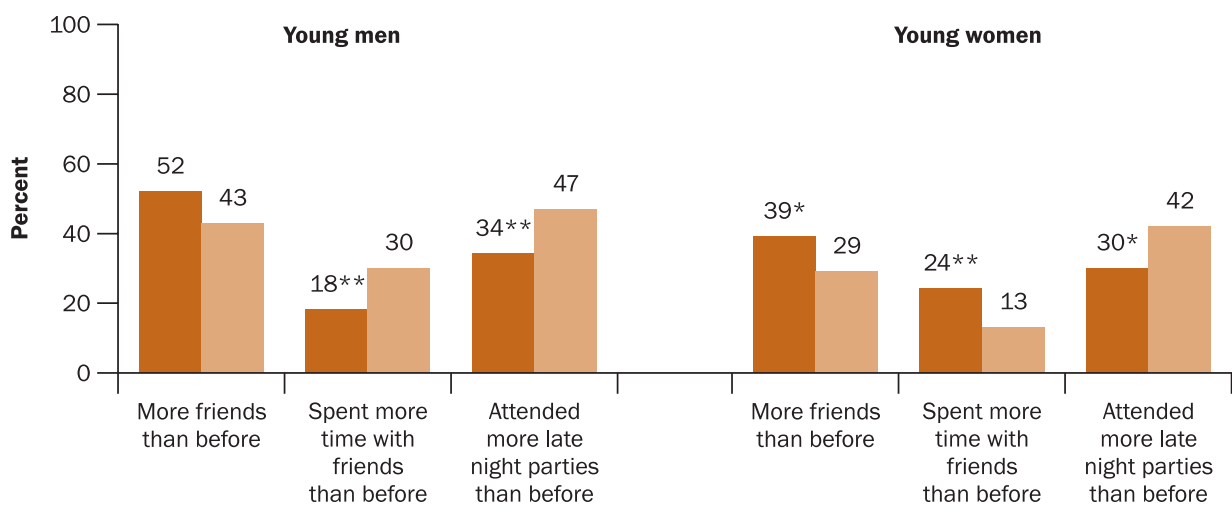


Figure 2 highlights differences in percentages reporting peers as leading confidantes on these matters by residence. Clearly, among young men, those residing independently were considerably more likely than those residing with their parents to report peers as leading confidante, irrespective of the topic. Among young women, interestingly, those residing with their parents were more likely than those residing independently to report peers as leading confidante on two of the three matters (personal problems and romantic relationship matters).

Figure 2:

Peer connections: \% reporting friends as their leading confidante on various matters by residence

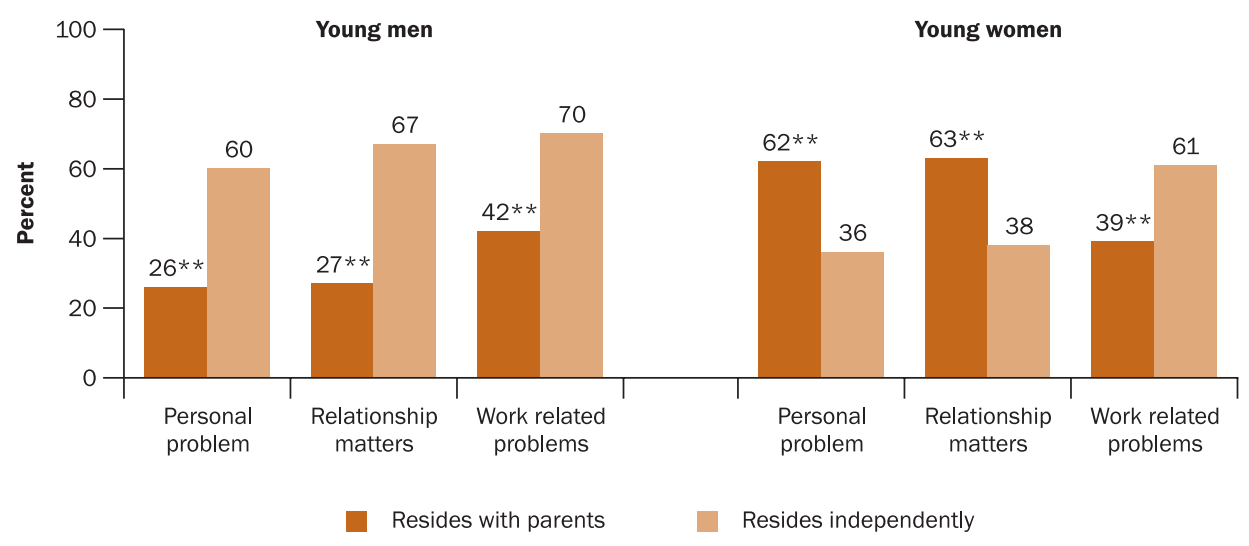

${ }^{*} p<=.01 ; * * p<=.001$. 


\section{Individual competencies}

This section discusses employees' perceptions of changes in their individual competencies, including their communication skills and self-efficacy, after making the transition to employment in a BPO. It also describes young adults' perceptions of their current negotiation skills and their assertiveness in reproductive and sexual health matters.

Although two-thirds of respondents reported being more stressed after joining a BPO, findings, presented in Table 12, indicate that large proportions of both young men and women agreed that working in the BPO sector had improved their communication skills and their self-efficacy. Gender differences were significant for most indicators of self-efficacy, with young women more likely than young men to attribute these changes to employment in a BPO. We acknowledge that these findings do not necessarily imply that young women working in the BPO were more assertive and confident than young men. Rather, they suggest that BPO employment was a major factor in enhancing young women's self-efficacy. It was less likely to be a major factor for young men who have traditionally had more opportunities to develop self-efficacy, and therefore, presumably higher pre-employment levels of self-efficacy.

As shown in Table 12, gender differences were apparent. Significantly more young women than young men agreed that after working in the BPO sector, they were more independent (91\% versus $86 \%$ ), confident ( $89 \%$ versus $74 \%$ ), more assertive ( $89 \%$ versus $69 \%$ ), more responsible ( $84 \%$ versus $68 \%$ ) more outgoing (68\% versus $52 \%$ ), as well as better able to resolve problems ( $80 \%$ versus $66 \%$ ) and manage their time ( $75 \%$ versus $55 \%$ ).

However, even when asked to discuss their negotiation skills, young women were significantly more likely than young men to report confidence in their ability to express an opinion to elders (48\% versus $39 \%$ ); confront a person with whom they disagreed (58\% versus $46 \%$ ); and tell their parents if they did not want to marry a person chosen by their parents $(71 \%$ versus $60 \%)$.

Although most employees perceived that employment in the BPO sector had made them more assertive and independent, findings, shown in Table 12, indicate that substantial proportions of young people were not confident or comfortable accessing reproductive health services or approaching health care providers. For example, only half of young men and 21 percent of young women felt comfortable buying contraceptives from a medical store. Fewer young men than young women (27\% versus $32 \%$ ) reported being comfortable discussing contraceptives with an adult or health provider.

As many as 90 percent or more young people, irrespective of gender, reported that they were able to save some money and most reported that they invested their savings either in individual bank accounts or fixed deposits. Significantly more young women than young men so reported (84\% versus $71 \%$ ). Moreover, significantly fewer young women than men reported that they kept their savings at home or gave their savings to their parents or others for safekeeping (13\% versus $24 \%$ ). 


\section{Table 12:}

Individual competencies post-employment in a BPO

\begin{tabular}{|c|c|c|}
\hline & $\begin{array}{l}\text { Young men } \\
(\mathbf{N}=\mathbf{8 8 2})\end{array}$ & $\begin{array}{l}\text { Young women } \\
\quad(\mathrm{N}=960)\end{array}$ \\
\hline \multicolumn{3}{|l|}{$\begin{array}{l}\text { Communication skills } \\
\% \text { reporting that post-employment in a BPO } \\
\text { they were: }\end{array}$} \\
\hline Better able to communicate & 85.5 & 84.2 \\
\hline \multicolumn{3}{|l|}{ Self-efficacy } \\
\hline \multicolumn{3}{|l|}{$\begin{array}{l}\% \text { reporting that post-employment in a } \mathrm{BPO} \\
\text { they were: }\end{array}$} \\
\hline More Stressed & 66.4 & 65.8 \\
\hline More independent** & 85.7 & 90.8 \\
\hline More confident** & 74.2 & 89.3 \\
\hline More assertive** & 69.2 & 88.6 \\
\hline More responsible** & 67.7 & 84.2 \\
\hline Better able to resolve problems** & 66.2 & 80.2 \\
\hline Better able to manage time** & 55.4 & 75.4 \\
\hline More outgoing** & 52.4 & 67.7 \\
\hline \multicolumn{3}{|l|}{$\begin{array}{l}\text { Negotiation skills } \\
\text { \% reporting they were confident about their } \\
\text { ability to: }\end{array}$} \\
\hline Express an opinion to elders** & 38.7 & 48.2 \\
\hline $\begin{array}{l}\text { Confront a person with whom they disagreed** } \\
\text { Tell their parents if they do not want to marry } \\
\text { the partner chosen by their parents** }\end{array}$ & 60.2 & 70.5 \\
\hline \multicolumn{2}{|l|}{$\begin{array}{l}\text { Assertiveness in sexual and reproductive } \\
\text { health matters }\end{array}$} & $\begin{array}{l}\% \text { reporting they were confident about their } \\
\text { ability to: }\end{array}$ \\
\hline Buy contraceptives from a medical store** & 49.7 & 20.8 \\
\hline $\begin{array}{l}\text { Discuss contraceptives with an adult or } \\
\text { health provider }\end{array}$ & 26.5 & 31.7 \\
\hline \multicolumn{3}{|l|}{ Savings pattern ${ }^{a}$} \\
\hline No savings** & 9.9 & 5.0 \\
\hline Formal saving** & 71.0 & 83.6 \\
\hline Informal saving** & 23.8 & 13.4 \\
\hline
\end{tabular}

${ }^{*} p<=.01 ; * * p<=.001$.

${ }^{\mathrm{a}}$ Multiple responses. 


\section{Awareness of sexual and reproductive health matters}

Many studies in India have highlighted young people's relatively low levels of awareness of sexual and reproductive health issues (IIPS and ORC Macro, 2007; Alexander et al., 2006a; IIPS and Population Council, 2009). This section discusses BPO employees' awareness of selected issues relating to pregnancy, contraception and the transmission of HIV.

Young adults were asked whether they agreed/disagreed with four statements on pregnancy and contraception, and the modes of HIV transmission (Table 13). It is interesting to note that although all the study participants were educated professionals, they lacked in-depth knowledge of sexual and reproductive health matters. For example, only about half of both young men and young women (55\% and 50\%) were aware that a woman can get pregnant at first sexual intercourse. Misconceptions about the modes of transmission of HIV were prevalent; 26 percent of young men and 22 percent of women believed that one can acquire HIV by kissing a person with HIV. In general, more young women than young men were aware about most pregnancy-related issues, including with regard to oral pills as a method to prevent pregnancy and the role of the condom in preventing pregnancy and protecting against HIV.

\section{Table 13:}

Awareness of reproductive and sexual health matters

\begin{tabular}{l|c|c|}
\hline Reproductive and sexual health matters & $\begin{array}{c}\text { Young men (\%) } \\
(\mathbf{N = 8 8 2})\end{array}$ & $\begin{array}{c}\text { Young women (\%) } \\
\text { (N=960) }\end{array}$ \\
\hline $\begin{array}{l}\text { A woman can get pregnant at first sexual } \\
\text { intercourse }\end{array}$ & 55.0 & 50.1 \\
Condoms protect against HIV** & 78.8 & 93.0 \\
Condoms prevent pregnancy* & 79.1 & 84.2 \\
Oral pills prevent pregnancy** & 59.4 & 86.9 \\
Withdrawal prevents pregnancy** & 52.7 & 32.6 \\
HIV is not transmitted by kissing an & & 77.8 \\
HIV-positive person & 74.4 &
\end{tabular}

${ }^{*} p<=.01 ;{ }^{* *} p<=.001$. 


\section{Romantic partnerships, physical intimacy and sexual experiences}

Several studies have noted that despite socio-cultural restrictions on heterosexual contacts, youth in India do find opportunities to interact and form romantic relationships, and to engage in premarital sex (Abraham, 2001; 2002; Abraham and Kumar, 1999; Alexander et al., 2006a; 2006b; Awasthi, Nichter and Pande, 2000). The prevalence and nature of romantic relationships among young adults and their experiences of premarital sex are discussed in this section. We also explore whether those residing with parents reported different experiences from those residing independently.

\section{Romantic relationships}

As seen in Table 14, the majority of youth (79\% of young men and $71 \%$ of young women) reported that they had been involved in a romantic relationship with an opposite-sex partner. Significantly more young women than young men $(50 \%$ versus $38 \%$ ) reported being in a romantic relationship at the time of interview.

Young men were more likely than young women to report more than one romantic partner; among those who had ever been in a romantic relationship, for example, 42 percent of young men as compared to 19 percent of young women reported three or more romantic partners. Two-fifths of young men and one-third of young women reported that they had more romantic partners after joining the BPO as compared to before working in the sector.

\section{Table 14:}

Romantic relations with an opposite-sex partner

\begin{tabular}{|c|c|c|}
\hline Romantic relations & $\begin{array}{l}\text { Young men (\%) } \\
\quad(\mathrm{N}=\mathbf{8 8 2})\end{array}$ & $\begin{array}{l}\text { Young women (\%) } \\
(\mathrm{N}=960)\end{array}$ \\
\hline Ever had a romantic partner** & 78.9 & 70.7 \\
\hline Currently has a romantic partner** & 38.3 & 49.6 \\
\hline $\begin{array}{l}\text { Among those who had a romantic partner }{ }^{\mathrm{a}} \text {, } \\
\text { number of partners:** }\end{array}$ & & \\
\hline 1 & 27.0 & 62.2 \\
\hline 2 & 31.0 & 19.1 \\
\hline $3+$ & 42.0 & 18.7 \\
\hline $\begin{array}{l}\text { Had more romantic partners post-employment in } \\
\text { a BPO than before* }\end{array}$ & 39.9 & 31.7 \\
\hline
\end{tabular}




\section{Physical intimacy and sexual experiences}

The study explored BPO employees' experiences of physical intimacy with an oppositesex partner, including whether they had kissed their partner, touched their partner's private parts and had sexual relations with their partner. As can be seen in Table 15, irrespective of gender, most young adults (67\% of young men and $64 \%$ of young women) reported that they had kissed their romantic partner and about half (55\% and $50 \%$, respectively) had touched their partner's private parts. A considerably larger proportion of young men than young women, however, reported engaging in sexual relations with their partner (48\% versus $35 \%$ ).

\section{Table 15:}

Experience of physical intimacy with an opposite-sex partner

\begin{tabular}{l|c|c|}
\hline Physical intimacy & $\begin{array}{c}\text { Young men (\%) } \\
(\mathbf{N}=\mathbf{8 8 2})\end{array}$ & $\begin{array}{c}\text { Young women (\%) } \\
(\mathbf{N}=\mathbf{9 6 0 )}\end{array}$ \\
\hline Kissed partner & 67.1 & 63.9 \\
Touched partner’s private parts & 55.0 & 49.8 \\
Had sexual relations with partner** & 47.7 & 34.6 \\
\hline${ }^{*} p<=.01 ; * * p<=.001$. & &
\end{tabular}

All respondents who had engaged in sexual relations with an opposite sex partner were asked about the nature of their first sexual experience. Findings, presented in Table 16, indicate that young men had initiated sexual relations at a younger age than young women. As expected, the majority of young men reported first sex with a younger partner and most young women reported first sex with an older partner.

Irrespective of gender, first sexual partners were largely colleagues (reported by $50 \%$ of young men and $58 \%$ of young women). One-fifth of young men and 15 percent of young women also reported persons from the neighbourhood as initial partners, while 15 percent of young men and 13 percent of young women reported first sex with a casual partner. For most respondents, the first sexual encounter had been at their own or their partner's residence. For about half of all respondents, first sex was experienced after they had taken their first job, frequently in the BPO sector.

While the vast majority of young adults noted that their first sexual experience had been consensual, gender differences were evident; young men were more likely than young women (91\% versus 79\%) to report consensual first sex. First sexual experiences tended to be spontaneous, with more than 70 percent of both young men and women reporting that the experience was unplanned. 


\section{Table 16:}

First sexual experience with an opposite-sex partner, among respondents reporting pre-marital sex

\begin{tabular}{|c|c|c|}
\hline Sexual experience & $\begin{array}{l}\text { Young men } \\
(\mathrm{N}=421)\end{array}$ & $\begin{array}{l}\text { Young women } \\
(\mathrm{N}=332)\end{array}$ \\
\hline \multicolumn{3}{|l|}{ Mean age at first sex among those aged (\%): } \\
\hline $20-21$ yrs** & 17.9 & 20.0 \\
\hline $22-23 \mathrm{yrs}^{* *}$ & 19.3 & 21.7 \\
\hline $24-25$ yrs & 21.8 & 22.3 \\
\hline Mean age of sexual partner** & 20.8 & 25.0 \\
\hline \multicolumn{3}{|l|}{ First sexual partner (\%) } \\
\hline Colleague & 49.9 & 58.4 \\
\hline Neighbour & 19.7 & 15.4 \\
\hline School/college friend & 15.7 & 13.3 \\
\hline Casual partner & 14.7 & 13.0 \\
\hline \multicolumn{3}{|l|}{ Place where sexual activity took place $(\%)$} \\
\hline Own/partner's residence & 70.5 & 72.3 \\
\hline Friend's residence & 14.5 & 13.3 \\
\hline Others $^{\mathrm{a}}$ & 15.0 & 14.4 \\
\hline \multicolumn{3}{|l|}{ Timing of first sex (\%) } \\
\hline First sex took place after taking first job & 47.5 & 53.6 \\
\hline \multicolumn{3}{|l|}{ Consensuality of first sex $(\%)^{* *}$} \\
\hline Persuaded by partner & 4.5 & 21.1 \\
\hline Persuaded partner & 5.0 & 0.0 \\
\hline Consensual & 90.5 & 78.9 \\
\hline Sexual experience unplanned (\%) & 70.1 & 74.4 \\
\hline \multicolumn{3}{|l|}{ Contraceptive use at first sex (\%) } \\
\hline Practised contraception & 45.8 & 53.9 \\
\hline \multicolumn{3}{|l|}{$\begin{array}{l}\text { Of those who practised contraception } \\
\% \text { who used:** }\end{array}$} \\
\hline Condoms & 75.6 & 62.0 \\
\hline Traditional methods & 19.7 & 35.8 \\
\hline Emergency contraception & 4.7 & 2.2 \\
\hline Of those who used condom, reason ${ }^{c}$ & & \\
\hline To prevent both infection and pregnancy & 69.6 & 62.2 \\
\hline
\end{tabular}


Corresponding to the unplanned nature of first sex, contraception was rarely practised, although young women were more likely than young men (54\% versus $46 \%$ ) to have used protection during their first sexual encounter, perhaps because they had initiated sex at a later age and were better informed about protection. Condoms were the preferred method of contraception reported by 76 percent and 62 percent of sexually experienced young men and women, respectively. Notably, among those who used a condom at first sex, half had done so to prevent both infection and pregnancy. In addition, 20 percent of young men and 36 percent of young women reported the use of traditional methods. In contrast to the large proportions reporting condom use, not a single BPO employee reported oral pill use at first sex and despite the fact that first sex frequently occurs spontaneously, emergency contraception was rarely used: just $2-5$ percent of young BPO employees had used this method in their first sexual encounter.

The survey also explored respondents' most recent sexual experience (Table 17). As in experiences of first sex, colleagues were the preferred partners in recent sexual encounters (as reported by $64 \%$ and $69 \%$ of young men and women, respectively); however, a larger percentage of youth reported colleagues as partners during their last sexual encounter as

\section{Table 17:}

Most recent sexual experience with opposite-sex partner, among respondents

\begin{tabular}{|c|c|c|}
\hline Last sexual experience & $\begin{array}{l}\text { Young men (\%) } \\
\quad(\mathrm{N}=421)\end{array}$ & $\begin{array}{c}\text { Young women (\%) } \\
\text { ( } \mathrm{N}=332)\end{array}$ \\
\hline \multicolumn{3}{|l|}{ Most recent sexual partner } \\
\hline Colleague & 64.6 & 72.9 \\
\hline Neighbour & 9.5 & 7.8 \\
\hline School/college friend & 10.7 & 6.6 \\
\hline Casual partner & 15.2 & 13.0 \\
\hline \multicolumn{3}{|l|}{ Contraceptive practice } \\
\hline Practised contraception & 68.6 & 65.1 \\
\hline Reported condom use at last sex** & 64.6 & 51.8 \\
\hline \multicolumn{3}{|l|}{$\begin{array}{l}\text { Of those who practised contraception }{ }^{\mathrm{a}} \text {, } \\
\% \text { who used:** }\end{array}$} \\
\hline Condoms & 92.4 & 75.6 \\
\hline Condoms and pills & 0.3 & 3.7 \\
\hline Oral pills & 0.3 & 3.2 \\
\hline Traditional methods & 5.8 & 15.2 \\
\hline Emergency contraceptive pills & 1.0 & 2.3 \\
\hline $\begin{array}{l}\text { Of those who used a condom } \text {, reason } \\
\text { To prevent both infection and pregnancy* }\end{array}$ & 75.6 & 82.0 \\
\hline \multicolumn{3}{|l|}{$\begin{array}{l}{ }^{*} p<=.01 ; * * p<=.001 \\
\text { a Young men }(N=291) ; \text { Young women }(N=217) \text {. } \\
{ }^{b} \text { Young men }(N=270) ; \text { Young women }(N=172) .\end{array}$} \\
\hline
\end{tabular}


compared to first sex. About one-fifth of young men and young women reported last sex with a casual partner, again an increase over the percentage reporting casual partners in first sexual encounters.

Young people's recent sexual experiences were more likely to be protected, with 69 percent of young men and 65 percent of young women reporting that they had used a contraceptive method during the last sexual encounter. Again the preferred method of contraception during recent sexual encounters was the condom, reported by 92 percent and 79 percent of young men and women who reported contraceptive practice at most recent sex. In contrast, just 6 percent and 15 percent reported traditional methods, 1 percent and 7 percent respectively, used oral pills and hardly any (1-2\%) reported emergency contraception.

Even so, findings suggest considerable risky sex (Table 18). A sizeable proportion of sexually experienced youth had engaged in sex with multiple partners; of those who ever had sexual relations, 66 percent and 33 percent of young men and women, respectively, reported having more than one sexual partner. Just one-third of all sexually experienced youth reported condom use at both first and last sexual relations; among those who had engaged in sexual relations with more than one partner, 46 percent among young men and 42 percent among young women reported condom use at both first and last sex.

Table 18:

Extent of risky sex

\begin{tabular}{|c|c|c|}
\hline & $\begin{array}{l}\text { Young men (\%) } \\
\qquad(\mathrm{N}=421)\end{array}$ & $\begin{array}{l}\text { Young women (\%) } \\
\qquad(\mathrm{N}=332)\end{array}$ \\
\hline $\begin{array}{l}\text { Multiple partner relations } \\
\text { \% reporting sex with more than one partner** } \\
\text { Consistent condom use } \\
\text { \% reporting condom use at first and last sexual } \\
\text { encounters } \\
\text { Consistent condom use among those reporting } \\
\text { sexual relations with multiple partners } \\
\text { \% reporting condom use at first and last } \\
\text { sexual encounters }\end{array}$ & 33.7 & 31.3 \\
\hline
\end{tabular}




\section{Residence patterns and romantic and sexual experiences}

In order to explore whether BPO employees who resided with their parents were less likely than those who resided on their own to report multiple partners, Figure 3 presents findings on their romantic relationships by residence patterns. Findings are inconsistent and do not lend support to the assertion that residence patterns affect the romantic relationship experiences of youth in BPOs. For example, residence with parents did not deter youth from engaging in romantic relationships over the course of their lives: more youth who resided with their parents than those who resided on their own reported ever being involved in a romantic relationship. However, while about equal percentages of young men and young women who resided with their parents reported being in a romantic relationship at the time of interview, significantly more young women who reported living on their own so reported. Conversely, among those who reported ever having a romantic relationship, young men who resided on their own were considerably more likely than those who resided with their parents to report multiple romantic partners; differences among young women were negligible.

Figure 3:

Romantic partnership and residence patterns

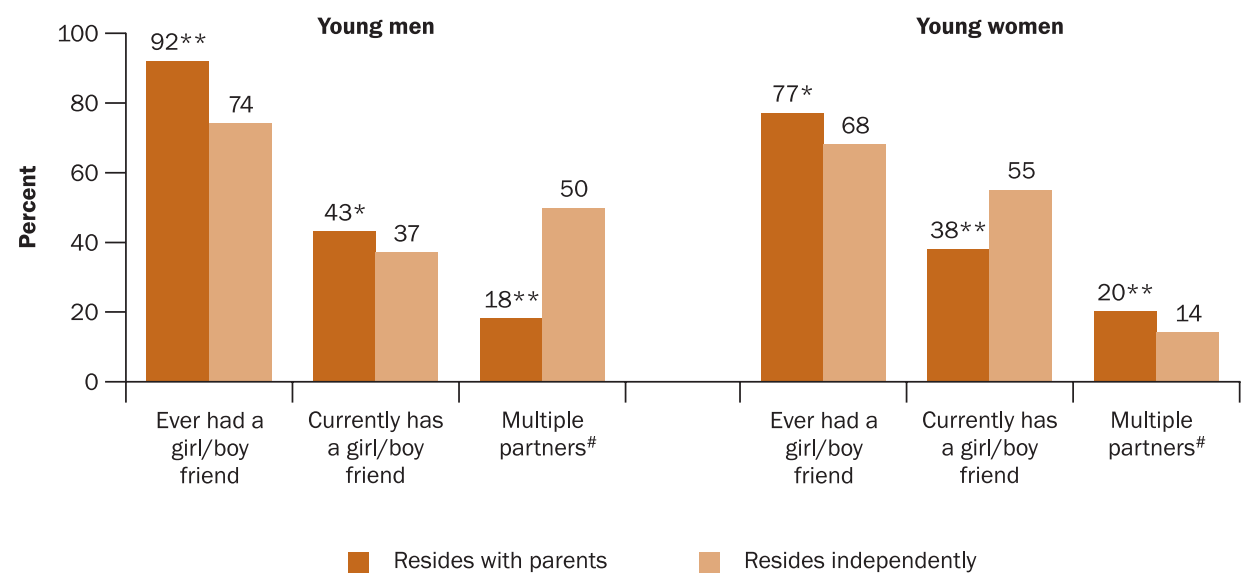

${ }^{*} p<=.01 ; * * p<=.001$.

\# reporting that they ever had a romantic partner 


\section{Figure 4:}

Physical intimacy by residence patterns

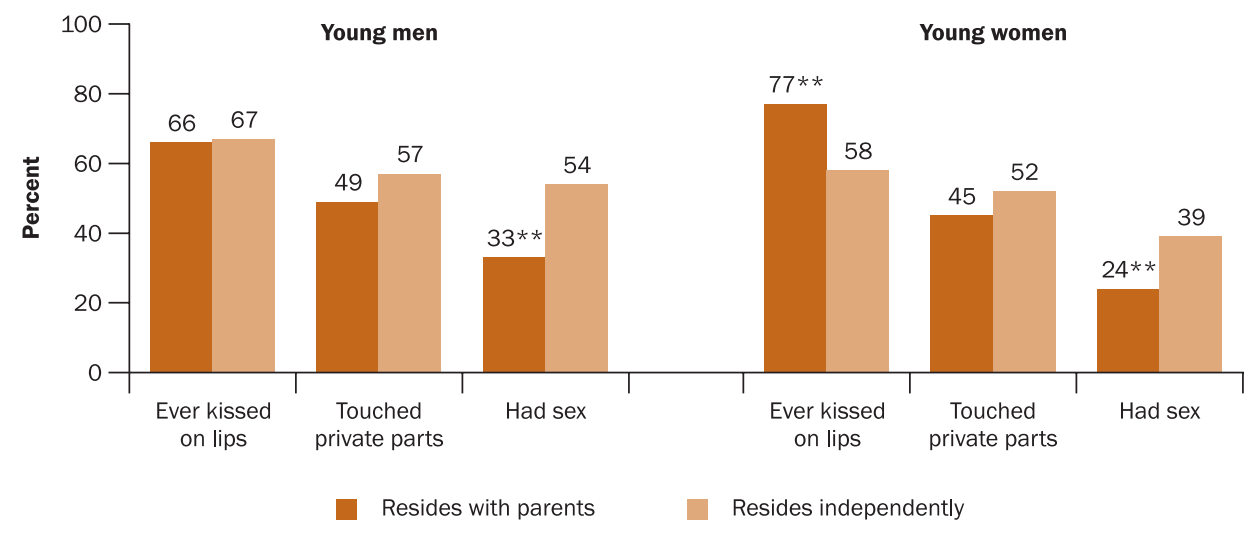

${ }^{*} p<=.01 ; * * p<=.001$.

Findings presented in Figure 4 explore the association between residence patterns and experience of physical intimacy. Again, findings are mixed. They suggest that experience of kissing was unrelated with residence among young men but that young women residing with their parents were actually more likely than those residing independently to report having kissed their romantic partner. However, evidence clearly shows that many more young men and women who resided independently than with parents reported having touched the private parts of, or engaged in sexual relations with the romantic partner. 


\section{Substance use}

Evidence from India has highlighted the links of substance use with risky sex (see, for example, Singh and Saini, 2007; Alexander, et al. 2006a). This section discusses the experiences of young people employed in the BPO sector with regard to substance use, including tobacco, alcohol and drugs, and among those who reported substance use, consumption characteristics (unfortunately, the survey did not probe the kinds of drugs consumed).

As seen in Table 19, a large proportion of young BPO employees reported smoking ( $72 \%$ of young men and $43 \%$ of young women) and even larger percentages reported the

\section{Table 19:}

Substance use

\begin{tabular}{|c|c|c|}
\hline Substance use & $\begin{array}{l}\text { Young men } \\
(\mathrm{N}=\mathbf{8 8 2})\end{array}$ & $\begin{array}{l}\text { Young women } \\
(\mathrm{N}=960)\end{array}$ \\
\hline Tobacco & & \\
\hline Ever smoked** & 71.7 & 43.0 \\
\hline Among those who ever smoked ${ }^{\text {a }}$, \% who: & & \\
\hline Started smoking at age 18 or below** & 50.8 & 31.5 \\
\hline Smoked more than once a week ${ }^{b * *}$ & 61.2 & 23.0 \\
\hline Alcohol & & \\
\hline Ever consumed alcohol** & 81.1 & 63.3 \\
\hline Among those who ever consumed alcohol ${ }^{\mathrm{C}}, \%$ who: & & \\
\hline Started drinking at age 18 or below** & 38.5 & 20.6 \\
\hline Drinks more than once a week $\mathrm{b}^{* *}$ & 32.4 & 11.0 \\
\hline Ever got drunk** & 70.9 & 34.5 \\
\hline Drugs $^{d}$ & & \\
\hline Ever used a drug** & 23.7 & 4.4 \\
\hline Among those who ever used a druge, \% who: & & \\
\hline Started using drugs at age 18 or below** & 29.2 & 100.0 \\
\hline Used drugs more than once a week ${ }^{b}$ & 10.0 & 0.0 \\
\hline Ever been high on drugs** & 58.9 & 0.0 \\
\hline
\end{tabular}

${ }^{*} p<=.01 ; * * p<=.001$.

${ }^{a}$ Young men $(N=632)$; Young women $(N=413)$.

${ }^{\mathrm{b}}$ In the 4 weeks preceding the survey.

${ }^{\mathrm{c}}$ Young men ( $\left.N=715\right)$; Young women $(N=608)$.

${ }^{\mathrm{d}}$ Includes cocaine and cannabis.

eYoung men ( $N=209)$; Young women $(N=42)$. 
consumption of alcohol (81\% and 64\%, respectively). Young people tended to initiate tobacco use earlier than alcohol consumption; among those who reported tobacco use, 51 percent of young men and 32 percent of young women had started smoking before 18 years while far fewer (39\% and 21\% respectively) of those who reported alcohol use had initiated consumed alcohol before 18 years. The large majority of young men (71\%) who had consumed alcohol reported that they had ever become drunk.

Gender differences were evident with regard to the use of tobacco and alcohol. Findings show that as compared to young women, young men were more likely to have ever smoked or consumed alcohol, initiated their use early and to have used these substances recently.

Drug use was also apparent; almost one in four young men had ever used a drug and three-fifths of those who had ever used a drug had been high on drugs. One-tenth of young men reported using drugs more than once a week in the four weeks preceding the survey. Interestingly, not a single young woman reported recent drug use; all young women who had taken drugs had done so at age 18 or below.

Findings clearly suggest that smoking, alcohol consumption and drug use were undertaken by many youth in adolescence, prior to joining the BPO sector and presumably when many were residing with their parents. As such, it is not surprising that youth who resided with their parents were more likely than those who resided independently to report smoking and alcohol consumption, as evident from Figure 5.

\section{Figure 5:}

Substance use and residence patterns: \% reporting ever having smoked or consumed alcohol

$\begin{array}{ll}\text { Young men } & \text { Young women }\end{array}$

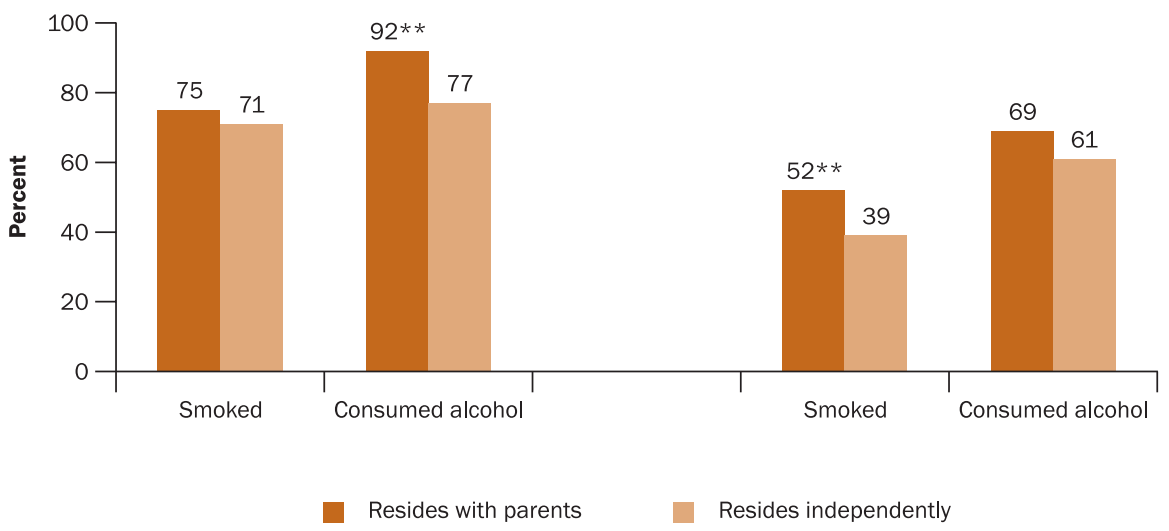

${ }^{*} p<=.01 ; * * p<=.001$. 


\section{Summing up and recommendations}

\section{Summing up}

The study was conducted among unmarried young people working in the BPO sector in Gurgaon. All the study participants had a college education, most were living away from their families, many reported that their families held non-traditional attitudes and that communication within the family was open. Of course, all were earning well. In these respects, the sample of young people in this study, particularly young women, is very different from youth in India more generally.

Although most young people were living on their own after joining the BPO, they shared a close and understanding relationship with their parents. Respondents reported being in regular contact with their parents, speaking to them on the telephone and visiting them at home regularly. Notably, two-fifths of young women reported that they contributed financially to their families with their earnings.

Employment in the BPO was perceived to have enhanced young people's communication skills and self-efficacy. However, young women were far more likely than young men to attribute changes in self-efficacy to their experience of working in a BPO. They were also more confident about their ability to negotiate with elders and their parents on issues about which they disagreed. At the same time, large proportions of young men and women reported that their lives were more stressful following BPO employment than before.

Peers were undoubtedly a key influence in the lives of young people. Indeed, for many, peer networks and social activities with friends had increased following employment in the BPO. Peers were leading confidantes on both personal and professional matters. In many ways, young people tended to emulate the behaviours of their peers; like their peers, a significant proportion of young men and young women had smoked and consumed alcohol.

The freedom that the new lifestyle afforded had provided young people with an opportunity to develop romantic relationships. Indeed, almost three-quarters of young people had been in a romantic relationship, and at the time of interview two-fifth of young men and half of young women were in a romantic partnership. Many young men had more than one romantic partner.

Almost half of young men and one-third of young women had also engaged in sexual relations. First sex for many young people was unplanned and unprotected, and for some women unwanted. In contrast, recent sex was protected for larger proportions of youth, and the condom was the method most likely to be used. In total, just one-third of sexually experienced BPO employees had used a condom consistently, that is, at both first and most recent sex, and considerable proportions, particularly among young men, had engaged in sex with more than one partner. 
Substance use was reported by more young men than young women. Large proportions of young men smoked and drank alcohol, and one-quarter had used drugs. The majority of young men who had consumed alcohol said they had got drunk at least once (71\%), and 59 percent of young men who had ever used a drug reported ever being high on the drug.

Although all the young people in our sample were educated professionals, findings suggest that they face health risks on various counts. Knowledge of pregnancy, HIV and protective methods among this sub-population was far from universal. Indeed, about one-quarter of respondents held at least one misconception about HIV transmission (that it can be transmitted by kissing an HIV+ person). Moreover, substantial proportions of youth perceived that they would not be comfortable accessing contraceptive supplies from a medical store or discussing contraception with health care providers or elders.

Evidence on whether experiences of BPO employees who resided with their parents differed from those of BPO employees who resided independently suggests that differences were indeed apparent. For example, while those who resided independently were indeed more likely to have engaged in sexual relations than those who resided with their parents, substance use was more likely to be reported by those who resided with their parents. Likewise, young men who resided independently were more likely than those who resided with their parents to report peers as leading confidantes on various matters; in contrast, more young women who resided with their parents than independently reported peers to be leading confidantes on two of the three matters probed.

\section{Recommendations}

The findings presented in this report reiterate that BPO employment does not only provide young adults with a profitable and challenging work environment, but also has other positive outcomes: many young BPO employees associated their increased independence and self-efficacy to their employment in this sector, many reported close peer networks, and many reported a savings orientation. However, several areas of concern were also observed, and these concerns call for a variety of interventions for youth in this sector.

Many BPO employees acknowledged high levels of stress associated with their jobs and while acknowledging that this is a competitive and demanding sector, BPOs need to consider measures that would alleviate some of this stress. Ambitious performance targets, strict deadlines and close monitoring may not be sustainable in the long-run and BPOs must review current practices and build in measures to counter employee burnout. Several youth had indicated recreational facilities as one of the best features of their BPOs and employees need to be provided opportunities to use these facilities. Finally, outlets for expressing stress—-to supervisors, managers or counsellors—need to be established to reduce stress experienced.

Findings that this well-educated population was lacking in sexual and reproductive health awareness reconfirms that even well-educated youth in India remain unexposed to sexuality education. This finding, combined with the finding of unsafe sexual relations 
among many young BPO employees argues strongly for BPOs to conduct sessions to raise awareness about sexual and reproductive matters for the young employees, perhaps in an anonymous on-line format or any other format that is acceptable.

Although for many, sexual relations had been initiated prior to joining the BPO sector, for many others, it had been initiated following BPO employment. Irrespective of when sexual relations were initiated, it took place without condoms and, as discussed above, many youth remained uninformed about contraceptive matters at the time of sexual initiation. Moreover, many youth would be embarrassed to seek contraceptive supplies from health care providers or even medical shops. There is clearly a need for health facilities at BPO level to incorporate such services as provision of contraceptive supplies and referrals for counselling, infection and so on.

Tobacco, alcohol consumption and drug use were reported by considerable proportions, especially young men, large proportions of whom reported ever being drunk. While fewer have taken drugs, considerable proportions of young men who had done so reported ever having been high on drugs. Awareness building efforts are needed that address the harmful effects of alcohol, tobacco and drug abuse; as well as to withstand peer pressure in these areas. 


\section{References}

Abraham, L. 2001. "Redrawing the lakshman rekha: Gender differences and cultural constructions in youth sexuality in urban India," South Asia 24:133-56.

Abraham, L. 2002. "Bhai-behen, true love, time pass: Friendships and sexual partnerships among youth in an Indian metropolis,” Culture, Health, and Sexuality 4(3):337-53.

Abraham, L. and K.A. Kumar. 1999. "Sexual experiences and their correlates among college students in Mumbai city, India,” International Family Planning Perspectives 25(3):139-46.

Alexander, M., L. Garda, S. Kanade et al. 2006a. Formation of partnerships among young women and men in Pune district, Maharashtra. New Delhi: Population Council.

Alexander, M., L. Garda, S. Kanade et al 2006b. Romance and sex: Pre-marital partnership formation among young women and men, Pune district, India,” Reproductive Health Matters 14 (28): 144-55.

Awasthi, S., M. Nichter and V.K. Pande. 2000. "Developing an interactive STD prevention programme for youth: Lessons from a north Indian slum," Studies in Family Planning 31(2):138-50.

Cleland, J. 2001. "Illustrative questionnaire for interview-surveys with young people," in Asking Young People about Sexual and Reproductive Behaviors: Illustrative Core Instruments, eds. J. Cleland, R. Ingham and N. Stone. Geneva: World Health Organization, Pp.5-16.

Elul, B., N. Sheriar, A. Anand et al. 2006. Are obstreticians-gynaecologists in India aware of and providing medical abortion? Journal of Obstetrics and Gynaecology, India, 56(4): 340-345.

e-sat survey. 2005. by IDC India Ltd for Dataquest magazine; <http://dqindia.ciol.com/ content/industrymarket/bpo/2005/105121103.asp>

Government of India, Department of Information and Technology. (n.d). Information technology, Annual report 2007-08, <http://www.mit.giv.in/download/annualreport2007-08>. New Delhi: Department of Information Technology.

International Institute for Population Sciences (IIPS) and ORC Macro. 2007. National Family Health Survey (NFHS-3), 2005-06: India, Volume 1. Mumbai: IIPS.

International Institute for Population Sciences (IIPS) and Population Council. 2009. Youth in India: Situation and Needs 2006-2007, Maharashtra. Mumbai: IIPS. 
International Institute for Population Sciences (IIPS) and Population Council. 2005. Youth in India: Situation and Needs 2006-2007, Draft Questionnaires. Mumbai: IIPS (unpublished).

Laird, R.D., G.S. Pettit, K.A. Dodge et al. 2003. Change in parents' monitoring knowledge: links with parenting, relationship quality, adolescent beliefs, and antisocial behaviour, Social Development 12 (3): 401-19.

Lambert, H. and K. Wood, 2005. A comparative analysis of communication about sex, health and sexual health in India and South Africa: Implications for HIV prevention,' Culture, Health and Sexuality 7(6): 527-41.

Marta, E. 1997. 'Parent-adolescent interactions and psychosocial risk in adolescents: An analysis of communication, support and gender,' Journal of Adolescence 20(5): 473-87.

Mehra, S., R. Savithri and L. Coutinho. 2002. "Sexual behaviour among unmarried adolescents in Delhi, India: Opportunities despite parental controls," paper presented at the IUSSP Regional Population Conference, Bangkok, June.

Phukan, P.J. 2003. "Changing HR paradigm in the ITES sector."

<http://www.itpeopleindia.com/20031006/cover.html> accessed on 10 November 2008.

Phukan P.J. 2006. The Changing Face of Indian Youth: Thanks to the BPO Industry, <http://www.path2usa.com/articles/article_bpo_121505.html>

Pradhan, J.P. and V. Abraham. 2005. Social and Cultural Impact of Outsourcing: Emerging Issues from Indian Call Centers Harvard Asia Quarterly, 9(3): 22-30.

Registrar General of India (RGI). 2001. Primary Census Abstract, Total Population: Table A-5, Series 1. New Delhi: RGI.

Sharma, S. n.d. "Human issues in call centers and BPO industry-A report" <www.BPOindia.org> accessed on June 1, 2009.

Sharma, S. 2004. "BPO industry in India—A Report"

$<$ www.BPOindia.org/research/bpo-in-india.html> accessed on 1 June, 2009.

Singh, S. and S. Saini. 2007. "HIV risk perception in relation to peer pressure and drug use abuse behaviour among adolescents," Indian Journal of sexually Transmitted Diseases 28: 53-54.

Sroufe, J.W. 1991. "Assessment of parent-adolescent relationships: Implications for adolescent development," Journal of Family Psychology 5(1):21-45.

<www.livemint.com/2007/11/17012831/Long-working-hours-travel-tim.html>. accessed on 1 June, 2009 


\section{Acknowledgements}

Several people provided invaluable assistance during the course of this study. I would like to thank the Corporate Communication and HR teams of the BPOs in Gurgaon for permitting me to undertake this sensitive but relevant research.

I would like to place on record my appreciation to Indira Varadarajan (Director SNS Foundation) for mentoring me and providing useful inputs throughout the study. I am also thankful to Kriti Bhardwaj for her support in data collection and entry and Rajendra Prasad, Information Systems and Data Management Consultant for guiding me with the data analysis.

I would like to thank Shireen Jejeebhoy, K.G. Santhya, Shveta Kalyanwala, Rajib Acharya, Francis Zavier and Komal Saxena at the Population Council for their guidance throughout the study and on previous versions of this report. Francis Zavier painstakingly reviewed tabulations and supported the statistical analysis and his contribution is much appreciated. I am also grateful to Usha Ram and Pertti J. Pelto for reviewing the report, to Deepika Ganju and Komal Saxena for editing the manuscript.

Finally I want to thank all the participants of the survey who gave their time and, above all, shared their valuable personal experiences on the various facets of the survey.

Last but not the least, my heartfelt gratitude to my family, without whose support this study would not have been possible. 
39 Exploring the Lives of Youth in the BPO Sector: Findings from a Study in Gurgaon 


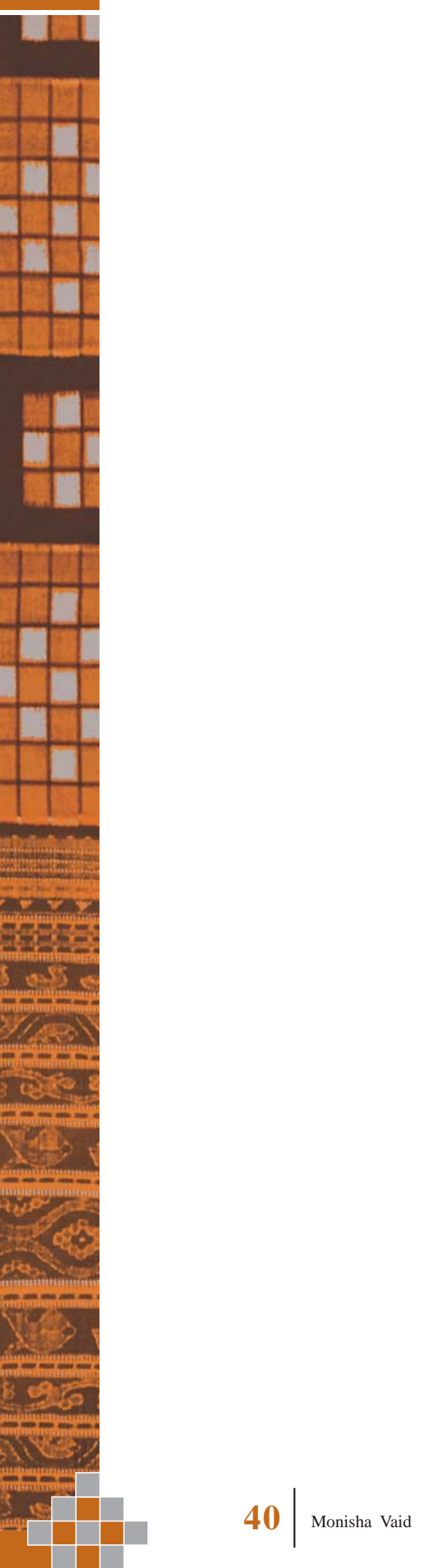



